\title{
Prediction of acid lactic-bacteria growth in turkey ham processed by high hydrostatic pressure
}

\author{
S.P. Mathias ${ }^{1}$, A. Rosenthal ${ }^{2}$, A. Gaspar ${ }^{3}$, G.M.F. Aragão ${ }^{4}$, A. Slongo-Marcusi ${ }^{5}$ \\ ${ }^{1}$ Universidade Federal Rural do Rio de Janeiro, Seropédica, RJ, Brazil. \\ ${ }^{2}$ Embrapa Agroindústria de Alimentos, Rio de Janeiro, RJ, Brazil. \\ ${ }^{3}$ Universidade Federal do Rio de Janeiro, Macae, RJ, Brazil. \\ ${ }^{4}$ Universidade Federal de Santa Catarina, EQA/CTC, Florianópolis, SC, Brazil. \\ ${ }^{5}$ Instituto Federal de Educação, Ciência e Tecnologia Fluminense, Cabo Frio, RJ, Brazil.
}

Submitted: September 18, 2010; Approved: August 22, 2012.

\begin{abstract}
High hydrostatic pressure (HHP) has been investigated and industrially applied to extend shelf life of meat-based products. Traditional ham packaged under microaerophilic conditions may sometimes present high lactic acid bacteria population during refrigerated storage, which limits shelf life due to development of unpleasant odor and greenish and sticky appearance. This study aimed at evaluating the shelf life of turkey ham pressurized at $400 \mathrm{MPa}$ for $15 \mathrm{~min}$ and stored at 4,8 and $12{ }^{\circ} \mathrm{C}$, in comparison to the non pressurized product. The lactic acid bacteria population up to $10^{7} \mathrm{CFU} / \mathrm{g}$ of product was set as the criteria to determine the limiting shelf life According to such parameter the pressurized sample achieved a commercial viability within 75 days when stored at $4{ }^{\circ} \mathrm{C}$ while the control lasted only 45 days. Predictive microbiology using Gompertz and Baranyi and Roberts models fitted well both for the pressurized and control samples. The results indicated that the high hydrostatic pressure treatment greatly increased the turkey ham commercial viability in comparison to the usual length, by slowing down the growth of microorganisms in the product.
\end{abstract}

Key words: high hydrostatic pressure, predictive models, lactic acid bacteria, turkey ham.

\section{Introduction}

Thermal treatment has been the basis of most processes industrially applied to ensure microbiological safety of foods. Recent consumer trends have led to technology innovation towards more healthy, nutritional and convenient foods. High hydrostatic pressure (HHP) treatment has been considered as one of the most promising nonthermal technology to preserve foods (Knorr 1993). It has been used in different food sector worldwide such as in fruit, dairy and meat products. In the meat sector, the technology offers a valuable alternative to the thermal pasteurization, especially for preserving convenience products (Rastogi et al., 2007).

HHP produces morphological, biochemical and genetic changes in microorganisms, and particularly affects their membranes and cell walls (Sangronis et al., 1997). It increases cell permeability and inhibits reactions and energy production by denaturing enzymes that are essential for growth and microbial reproduction (Calderón-Miranda et al., 1998). The treatment can ensure the destruction of up to $8 \log$ units of certain types of bacterial cells, without altering the flavor and nutritional value of foods (Dogman and Erkmen, 2004). The capacity of microorganisms destruction or inactivation by high hydrostatic pressure varies according to the pressure level, time and temperature of pressurization, the type of microorganism and its growth stage, as well as the food composition (mainly depending on the $\mathrm{pH}$ and water activity) (Rosenthal and Silva, 1997; Calderón-Miranda et al., 1998).

A cured cooked meat product is a perishable product spoiled mainly by acid lactic bacteria (LAB) which cause discoloration, slime formation, off-odors and off-flavors as the result of their metabolic activity leading to the produc- 
tion of various compounds. These microbial products in conjunction with the microbial population could be used to assess the degree of spoiled of this type of product (Mataragas et al., 2007). When meat products are stored under refrigeration and microaerophilic conditions, such as vacuum or modified atmosphere packaging, lactic acid bacteria may very often predominate in the product deterioration. Since these products are commonly heated within the range of 68 to $75{ }^{\circ} \mathrm{C}$, most vegetative cells are killed and recontamination of the post-heating products determines the commercial validity (Borch et al., 1996; Vermeiren et al., 2004). The recontamination after cooking, especially by the microbiota present in industrial environment is considered as the main factor which affects the shelf life of meat products, along with the storage temperature (Samelis et al., 1998). Typically, the initial count of lactic acid bacteria in meat products packaged under vacuum is low, but increases during refrigerated storage and may cause evident deterioration when the count reaches 7 to $8 \log 10 \mathrm{CFU} / \mathrm{g}$ (Santos et al., 2005; Vermeiren et al., 2005).

The prediction of shelf life allows companies to optimize their storage management and it is, due to the minimization of economic losses, one of the most important company planning issues these days (Raab et al., 2008). During the last years, several models have been developed to predict the growth of the specific spoilage organism (SSO) in fresh food products such as meat and fresh meat products (Baranyi et al., 1995; Mataragas et al., 2006; Gospavic et al., 2008). The majority of the shelf-life models for chilled products describe the growth of SSOs depending on the temperature which is generally consider the most important influencing factor of shelf life (Zwietering et al., 1991; McMeekin et al., 1992). Food microbiologists have sought efficient models to describe and predict microbial growth and its consequences during food storage (Baranyi and Roberts, 1994). A classic model has been used in the characterization of bacterial growth considering the three following parameters: the lag phase $(\lambda)$ the maximum specific growth rate $(\mu)$ and the maximum population density within a certain growth period (A) (Baty et al., 2004).

This study aimed at modeling the growth of lactic acid bacteria in pressurized turkey ham in comparison to the unpressurized product (control) at different storage temperatures, estimating the trade product validity in each case.

\section{Material and Methods}

\section{Sampling}

Frozen turkey legs packed in small plastic bags were purchased in a Brazilian supermarket. The packages contained about $1.2 \mathrm{~kg}$ each, and were grouped in cardboard boxes with $15 \mathrm{~kg}$ each for commercialization, the manufacturing company from South Brazil works with special cuts of frozen turkey and delivers the products in tempera- ture-controlled trucks, following all the basic requirements of hygiene and conservation. The turkey leg packages are stored at $-18{ }^{\circ} \mathrm{C}$ in freezer up to the commercialization.

\section{Preparation of the samples}

The experimental work was carried out at Embrapa Food Technology. For the manufacture of ham first a "toilet" was carried out on defrost turkey thighs using knives for removing bones, tendons, nerves, and skin, and to cut down the meat into small pieces. A commercial formulation of additives and spices purchased from the company Duas Rodas Industrial ${ }^{\circledR}$ was used in the ham preparation. Brine mixture was weighed and diluted in cold water, by constantly stirring up to complete dissolution until it was added to the meat. The meat mixed with brine was taken to a "cutter" (Geiger, model UM12) in which alternating operations ( 2 or 3 ) were carried out for few seconds each, in order to first reduce the meat into smaller pieces and then to obtain a more homogeneous mass in the end. Next it was transferred to a plastic container covered with a lid and taken to a refrigerator, where it remained for $24 \mathrm{~h}$ at $5{ }^{\circ} \mathrm{C}$. After that period, the mass in portions of $2.5 \mathrm{~kg}$ each in average was vacuum packaged in thermal resistant plastic bag (cook-in) and placed in stainless steel cooking forms. The cooking was carried out at $72{ }^{\circ} \mathrm{C}$ in autoclave. Temperatures was monitored with a temperature indicator (model $E L L A B)$ throughout thermocouples placed in different portions of the control. After cooking, the product was cooled down in ice bath for $40 \mathrm{~min}$ and then stored in a refrigerator at $4{ }^{\circ} \mathrm{C}$ for $24 \mathrm{~h}$. After that period, the turkey ham was ready to the the high hydrostatic pressure treatment. The pieces of turkey ham were sliced (SKYMSEN, model CFI-300) into $0.5 \mathrm{~mm}$ thickness slices and vacuum packaged in plastic bags, being kept in cold room up to the processing time. For aseptic assurance all manipulation was carried out inside an air flow chamber (Booth FLV-K, series 256-8I) being all materials exposed to UV light for at least $15 \mathrm{~min}$.

\section{High hydrostatic pressure treatment}

The high hydrostatic pressure equipment used was a laboratory model (Stansted Fluid Power, model S-FL-850$9-W$ ). The equipment had the capacity to operate within a pressure range between $100 \mathrm{MPa}$ to $900 \mathrm{MPa}$, and temperatures between 0 to $80{ }^{\circ} \mathrm{C}$. The equipment was controlled through a digital panel for adjusting pressure, time and temperature. The turkey ham samples were placed inside the cylinder-shaped stainless steel sample holder, containing several holes through which circulates the pressurizing liquid, in that case $70 \%$ alcohol. At the end of the process, the chamber was opened and samples were taken from the pressurized cylinder and destined to microbiological analyses. The pressure treatment at $400 \mathrm{MPa}$ for 15 min was applied at room temperature, based on the results obtained by Slongo et al. (2009), who investigated the pressure treatment of pork ham. According to that study the selected op- 
erational conditions significantly increased the product commercial viability (cv) and preserved its sensory properties, being therefore adopted in the present study.

\section{Microbiological analysis}

To perform the microbiological testing, samples were handled inside the flow chamber being aseptically removed and divided into sterile bags (Nasco WHILE-PACK ${ }^{\circledR}$ ) containing $25 \mathrm{~g}$ each. The packages were then vacuum packed and stored at 4,8 and $12{ }^{\circ} \mathrm{C}$ for 75 days.

The commercial viability of pressurized and non treated (control) turkey ham was determined based on lactic acid bacteria growth (LAB) following the methodology described by Hall et al. (2001). From each piece of turkey ham $25 \mathrm{~g}$ of product were aseptically sampled, placed in sterile bags with the addition of $225 \mathrm{~mL}$ of peptone water (1\%). Samples were homogenized for $60 \mathrm{~s}$ in stomacher, diluted and plated on culture agar of Man, Rogosa, Sharp (MRS) followed by incubation at $30^{\circ} \mathrm{C}$ for 5 days. The analyses were performed in duplicate and results were expressed in $\log (\mathrm{N})(\mathrm{N}$ : colony forming unit per gram $[\mathrm{CFU} / \mathrm{g}])$, until microorganism growth reached the stationary phase.

\section{Validation of the predictive modeling}

The predictive models of Modified Gompertz and Baranyi were adjusted to the growth curves using the softwares Matlab ${ }^{\circledR}$ (Math Works, Natick, MA, USA) and DMFit 2.1 (Baranyi and Roberts, 1994), respectively.

The Modified Gompertz Model (Gibson et al., 1987) is defined by the following equation:

$$
\log \left(\frac{N}{N_{0}}\right)=A \cdot \exp \left\{-\exp \left[\frac{\mu \cdot e}{A}(\lambda-t)+1\right]\right\}
$$

where $\lambda$ is the extension of lag phase (days); $\mu$ is the rate of exponential microbial growth (days $\left.{ }^{-1}\right), A$ is the logarithmic increase of population and $t$ is time of storage.

The Baranyi Model (Baranyi and Roberts, 1994) is represented by the equation below, where $A, B, C$ and $D$ are mathematically rearranged:

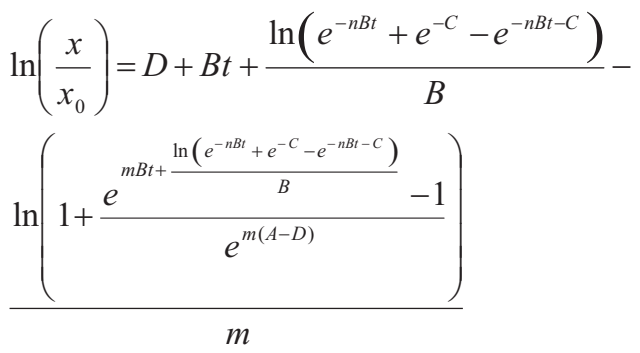

Constants have the following physical meaning:

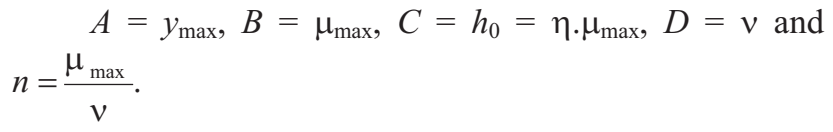

\section{Statistical analysis}

The following statistical indices were used in order to compare the performance of models: mean-squared error (MSE), regression coefficient $\left(\mathrm{R}^{2}\right)$, bias factor and accuracy factor. The lower the value of MSE, the better is the fit of the model to experimental data (Sutherland and Bayliss, 1994). The MSE is defined according to the following equation:

$$
M S E=\sum \frac{(O-P)^{2}}{(n-p)}
$$

In which $\mathrm{O}$ represents the observed value, $P$ is the predictive value, $n$ is the number of experimental points and $p$ is the number of model parameters). The bias factor is represented by the equation:

$$
B F=\exp \left[\Sigma\left(\ln \frac{P}{O}\right) / n\right]
$$

and consists of an estimate for the average difference between the observed and predicted and ideally should be close to 1 . If the value is greater than 1 , it indicates that the expected value is bigger than the observed one, but if it is lower, it indicates that the predicted value is smaller than the one observed. The accuracy factor is the sum of absolute differences between predictions and observations values and measures the overall error of the model, being calculated by the following equation:

$$
\begin{aligned}
& A F=\exp [((L N P-L N O) 2 / n) 0.5] \text { accuracy factor }= \\
& { }_{10}\left(\sum \frac{\left.\sum^{\mid \log \left(\text { Value }_{\text {prediced }} / \text { Value }_{\text {observed }}\right)}\right)}{n}\right)
\end{aligned}
$$

The higher the accuracy factor, the lower the accuracy of the average estimate.

\section{Results and Discussion}

The microbiological parameters of growth (Ross, 1996): ( $A, \mu, \lambda$ for the lactic acid bacteria growth in turkey ham are presented in Table 1. These results were obtained by fitting the modified Gompertz model to the LAB growth curves at the storage temperature of 4 and $12{ }^{\circ} \mathrm{C}$, both for the control and pressurized samples. For the control and pressurized samples at $8^{\circ} \mathrm{C}$, the modified Gompertz model did not provide a good fit and the Baranyi model was rather used for a better fit of the curves.

The experimental and adjusted LAB growth curves under different storage conditions, according either to the Modified Gompertz or Baranyi models, are shown in Table 2 . 
Table 1 - Kinetic parameters for growth of lactic acid bacteria adjusted to Modified Gompertz and Baranyi models.

\begin{tabular}{|c|c|c|c|c|c|c|c|c|c|c|}
\hline \multirow[b]{2}{*}{$\mathrm{T}\left({ }^{\circ} \mathrm{C}\right)$} & \multicolumn{5}{|c|}{ Control } & \multicolumn{5}{|c|}{ Pressurized } \\
\hline & CV (days) & A & $\lambda$ (days) & $\mu\left(\right.$ day $\left.^{-1}\right)$ & $r^{2}$ & CV (days) & A & $\lambda$ (days) & $\mu\left(\right.$ day $\left.^{-1}\right)$ & $\mathrm{R}^{2}$ \\
\hline & \multicolumn{5}{|c|}{ Modified Gompertz model } & \multicolumn{5}{|c|}{ Modified Gompertz model } \\
\hline \multirow[t]{2}{*}{4} & 40 & 6401 & 25 & 0.4326 & 0.948 & 75 & 6767 & 19 & 0.1501 & 0.956 \\
\hline & \multicolumn{5}{|c|}{ Baranyi Model } & \multicolumn{5}{|c|}{ Baranyi Model } \\
\hline \multirow[t]{2}{*}{8} & 25 & - & - & 0.2387 & 0.976 & 65 & - & - & 0.0841 & 0.959 \\
\hline & \multicolumn{5}{|c|}{ Modified Gompertz model } & \multicolumn{5}{|c|}{ Modified Gompertz model } \\
\hline 12 & 24 & 6208 & 6 & 0.4521 & 0.984 & 30 & 7047 & 5 & 0.317 & 0.999 \\
\hline
\end{tabular}

Table 2 - Statistics obtained from the fitting of lactic acid bacteria growth to modified Gompertz and Baranyi models in pressurized vacuum packed turkey ham in comparison to the control, stored at 4,8 and $12{ }^{\circ} \mathrm{C}$.

\begin{tabular}{lcccc}
\hline Predictive model & \multicolumn{4}{c}{ Statistical parameters } \\
\cline { 2 - 5 } & $\mathrm{r}^{2}$ & MSE & Bias factor & Accuracy factor \\
\hline Control stored at $4{ }^{\circ} \mathrm{C}$ & & \\
Modified Gompertz model & 0.948 & 0.05878 & 0.9989 & 1.0294 \\
& Pressurized stored at $4{ }^{\circ} \mathrm{C}$ & & \\
Modified Gompertz model & 0.9586 & 0.11615 & 0.9989 & 1.0864 \\
& Control stored at $8{ }^{\circ} \mathrm{C}$ & & \\
Baranyi model & 0.9768 & 0.09382 & 1 & 1.0396 \\
Baranyi model & Pressurized stored at $8{ }^{\circ} \mathrm{C}$ & & 1.0437 \\
& 0.9595 & 0.1394 & 1.0078 & \\
Modified Gompertz model & Control stored at $12{ }^{\circ} \mathrm{C}$ & & 1.01812 \\
& 0.9843 & 0.0254 & 1.00195 & \\
Modified Gompertz model & 0.9999 & 0.00017 & 0.99967 & 1.00203 \\
\hline
\end{tabular}

The storage temperature proved to have a great influence on the growth of LAB. The results showed the importance of maintaining low temperatures in order to achieve greater commercial viability, and also that the use of high hydrostatic pressure highly increased commercial validity by slowing down the LAB growth. Such implications were evident from the fact that the pressurized turkey ham stored at $12{ }^{\circ} \mathrm{C}$ showed greater validity when compared to the control ham stored at $8^{\circ} \mathrm{C}$. It was also observed that at $4{ }^{\circ} \mathrm{C}$ the commercial viability of the control achieved 45 days, while the pressurized sample lasted up to 75 days, providing 30 extra days for commercialization.

To date, most studies on the effect of high pressure treatment on the microbiota of ready-to-eat and meat products have been directed to refrigerated post processing storage at a temperature of $4{ }^{\circ} \mathrm{C}$, instead of including temperature abuse evaluation (Kreyenschmidt et al., 2009). In this study a higher temperature $\left(12^{\circ} \mathrm{C}\right)$ was also used aiming at reproducing possible unexpected temperature abuse that can occur in storage and to allow the prediction by the models of the product commercial validity under unfavorable conditions. It was verified that even at higher temperatures high pressure processed turkey ham showed satisfactory shelf-life, when compared with the control stored at a lower temperature, based on lactic bacteria growth.

Figure 1 represents the growth curves of lactic acid bacteria according to storage temperatures at 4,8 and $12{ }^{\circ} \mathrm{C}$, applying predictive models of modified Gompertz and Baranyi. The curves of microbial growth presented in overall good fit, giving important information about the potential growth of lactic bacteria and commercial viability of turkey ham for each storage temperature.

In pork ham treated at $400 \mathrm{MPa}$ for $15 \mathrm{~min}$ and stored at $8{ }^{\circ} \mathrm{C}$, Slongo et al. (2009) achieved a commercial viability of 85 days in comparison to the control, which lasted only 19 days. Those results are similar to the ones obtained for turkey ham in the present study using the same processing and storage conditions, in which the pressurized sample showed commercial viability of 65 days and the control sample just lasted 25 days. According to the studies by Ruiz-Capillas (2007), the high-pressure treatment at $400 \mathrm{MPa}$ for $10 \mathrm{~min}$ applied to vacuum packaged ham pro- 

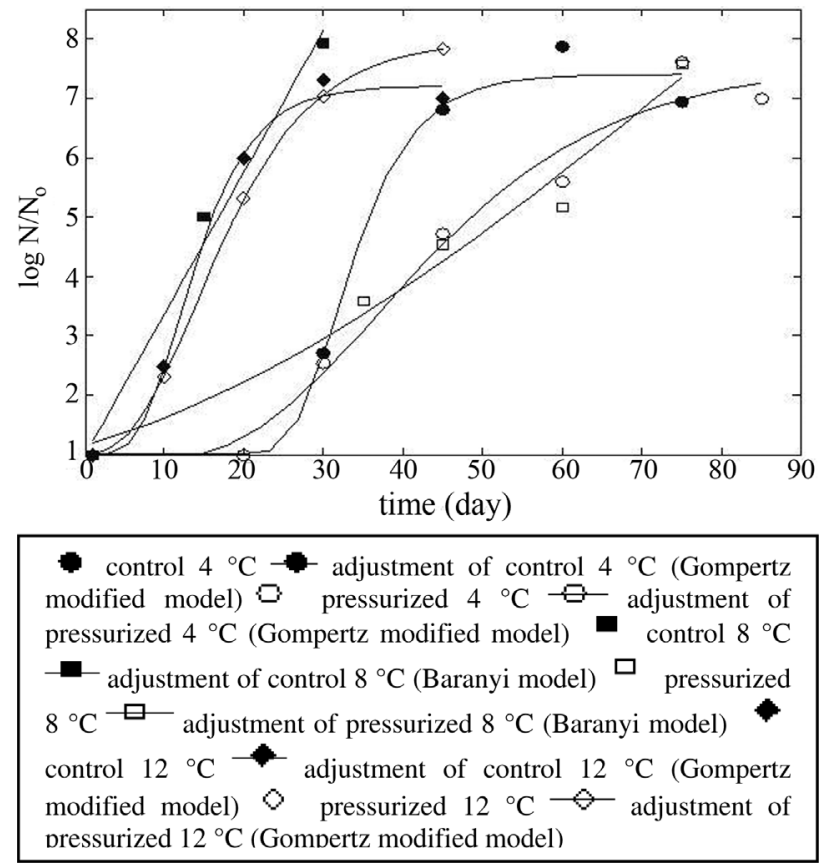

Figure 1 - Growth curves of lactic acid bacteria resulting from the fit to modified Gompertz and Baranyi models in control and pressurized turkey ham stored at different storage temperatures.

vided a commercial validity of 77 and 28 days for products stored at 2 and $12{ }^{\circ} \mathrm{C}$, respectively. However, López-Caballero et al. (1999), with the same type of product but treated at $200 \mathrm{MPa}$ and $400 \mathrm{MPa}$ did not attain the same degree of inactivation, and the commercial viability at $3{ }^{\circ} \mathrm{C}$ resulted only in 21 days.

At higher pressures, such as those used by Slongo et al. (2009) with ham slices pressurized at $600 \mathrm{MPa}$ for $5 \mathrm{~min}$ at $30^{\circ} \mathrm{C}$ and stored at $5{ }^{\circ} \mathrm{C}$ for 120 days, LAB population did not increase significantly during the storage. Park et al. (2001) in studies with ham processed at $600 \mathrm{MPa}$ for $5 \mathrm{~min}$ and $25^{\circ} \mathrm{C}$ showed a reduction of $\sim 4 \log 10 \mathrm{CFU} / \mathrm{g}$ of LAB due to the processing. Garriga et al. (2004) reported that vacuum packaged ham treated at $600 \mathrm{MPa}$ for 4 min at $16{ }^{\circ} \mathrm{C}$ showed LAB count after 30 days of $2.10 \log 10$, and observed a significant microbial inactivation due to the pressure treatment. That also agrees with the results from Carpi et al. (1999), which reported 75 days of commercial viability for sliced cooked ham treated at $600 \mathrm{MPa}$ for 5 min and stored at $4{ }^{\circ} \mathrm{C}$.

\section{Conclusion}

Application of High Hydrostatic Pressure at $400 \mathrm{MPa}$ and $15 \mathrm{~min}$ was effective to greatly delay lactic bacteria growth in turkey ham during refrigerated storage. The time required for the LAB population to achieve the limit defined for the product validity was longer for the pressurized sample stored at $12{ }^{\circ} \mathrm{C}$ even when compared to the non treated control sample stored at $8^{\circ} \mathrm{C}$. Both Modified Gompertz and Baranyi models provided good fit for the varia- tion of lactic acid bacteria population with the storage time, showing high determinant coefficients for the regression adjustments. Modified Gompertz models presented better fit for the lactic bacteria growth for both pressurized and control sample, either stored at $4{ }^{\circ} \mathrm{C}$ or $12{ }^{\circ} \mathrm{C}$, while Baranyi model presented a better fit for samples stored at $8^{\circ} \mathrm{C}$. Predictive microbiology proved to be a valuable tool to provide a good estimative of the product validity based on lactic bacteria growth, and high hydrostatic pressure demonstrated was very effective to delay microbial development and provide shelf life extension to the turkey ham.

\section{Acknowledgments}

Financial support: FAPERJ and FINEP (Brazil) for funding the project and CAPES for awarding the scholarship.

Equipments and infra-structure: Processing and analyses were carried out at Embrapa Food Technology (Rio de Janeiro, Brazil).

\section{References}

Baranyi J, Robinson TP, Kaloti A, Mackey BM (1995) Predicting growth of Brochothrix thermosphacta at changing temperature. Int J Food Microbiol 27:61-75.

Baranyi J, Roberts TA (1994) A dynamic approach to predicting bacterial growth in food. Int J Food Microbiol 23:277-294.

Baty F, Delignette-Muller ML (2004) Estimating the bacterial lag time: Which model, which precision? Int J Food Microbiol 91:261-277.

Borch E, Kant-Muermans ML, Blixt Y (1996) Bacterial spoilage of meat and cured meat products. Int J Food Microbiol 33:103-120.

Calderón-Miranda ML, González MFSM, Barbosa-Cánovas GV, Swanson BG (1998) Métodos no térmicos para procesamiento de alimentos: Variables e inactivación microbiana. Braz J Food Technol 1:3-11.

Carpi G, Squarcina N, Gola S, Rovere P, Pedrielli R, Bergamaschi M (1999) Application of high pressure treatment to prolong the refrigerated shelf-life of sliced cooked ham. Industria Conserve 74:327-339.

Dogman C, Erkmen O (2004) High pressure inactivation Kinetics of Listeria monocyogenes inactivation in broth, milk, and peach and orange juice. J Food Eng 62:47-52.

Gospavic R, Kreyenschmidt K, Bruckner S, Popov V, Haque N (2008) Mathematical modelling for predicting the growth of Pseudomonas ssp. in poultry under variable temperature conditions. Int J Food Microbiol 127:290-297.

Hall PA, Ledenbach L, Flowers RS (2001) Acid producing microorganisms. In: Downes FP and Ito K (eds). Compendium of Methods for the Microbiological Examination of Foods. $4^{\text {th }}$ ed. American Public Health Association, Washington, pp 201-207.

Knorr D (1993) Effects of high hydrostatic pressure processes on food safety and quality. Food Technology 47:156-161.

Kreyenschmidt J, Hübner A, Beierle E, Chonsch A, Scherer A, Petersen B (2009) Determination of the shelf life of sliced cooked ham based on the growth of lactic acid bacteria in different steps of the chain. J Appl Microbiol 108:510-520. 
López-Caballero ME, Carballo J, Jimenez-Colmenero (1999) Microbiological changes in pressurized, prepackaged sliced cooked ham. J Food Prot 62:1411-1415.

Mataragas M, Drosinos EH, Vaidanis A, Metaxopoulos, I (2006) Development of a predictive model for spoilage of cooked cured meat products and its validation under constant and dynamic temperature storage conditions. J Food Sci 71:157-167.

Mataragas M, Skandamis P, Nychas G-JE, Drosinos EH (2007) Modeling and predicting spoilage of cooked, cured meat products by multivariate analysis. Meat Science 77:348356.

McMeekin TA, Ross T, Olley J (1992) Application of predictive microbiology to assure the quality and safety of fish and fish products. Int J Food Microbiol 15:13-32.

Park SW, Sohn KH, Shin JH, Lee HJ (2001) High hydrostatic pressure inactivation of Lactobacillus viridescens and its effect on ultrastructure of cells. Int J Food Sci Technol 36:775-781.

Raab V, Bruckner S, Beierle E, Kampmann Y, Petersen B, Kreyenschmidt J (2008) Generic model for theprediction of remaining shelf life in support of cold chain management in pork and poultry supply chains. Journal on Chain and Network Science 8:59-73.

Rastogi NK, Raghavarao KSMS, Balasubramaniam VM, Niranjan K, Knorr D (2007) Opportunities and challenges in high pressure processing of foods. Crit Rev Food Sci Nutr 47:69112.

Rosenthal A, Silva JL (1997) Alimentos sob pressão. Engenharia de Alimentos 14:37-39.

Ross T (1996) Indices for performance evaluation of predictive models in food microbiology. J Appl Microbiol 81:501-508.

Ruiz-Capillas C, Carballo J, Colmenero FJ (2007) Biogenic amines in pressurized vacuum-packed cooked sliced ham under different chilled storage conditions. Meat Science 75:397405.

Samelis J, Kakouri A, Georgiadou KG, Metaxopoulos J (1998) Evaluation of the extent and type of bacterial contamination at different stages of processing of cooked ham. J Appl Microbiol 84:649-660.

Sangronis E, Pothakamury U, Ramos AM, Ibraz A, BarbosaCánovas GV, Swanson BG (1997) La alta presión hidrostática: Una alternativa en el procesamiento no térmico de los alimentos. Alimentaria 283:33-43.

Santos EM, Jaime I, Rovira J, Lyhs U, Korkeala H, BjeOrkroth J (2005) Characterization and identification of lactic acid bacteria in "Morcilla de Burgos". Int J Food Microbiol 97:285296.

Slongo AP, Rosenthal A, Camargo LMQ, Deliza R, Mathias SP and Aragão GMF.(2009). Modeling the growth of lactic acid bacteria in sliced ham processed by high hydrostatic pressure. LWT- Food Sci Technol 42:303-306.

Sutherland JP, Bayliss AJ (1994) Predictive modelling of growth of Yersinia enterocolitica: The effects of temperature, $\mathrm{pH}$ and sodium chloride. Int J Food Microbiol 21:197-215.

Vermeiren L, Devlieghere F, Debevere J (2004) Evaluation of meat born lactic acid bacteria as protective cultures for the biopreservation of cooked meat products. Int J Food Microbiol 96:149-164.

Vermeiren L, Devlieghere F, De Graef V, Debevere J (2005) In vitro and in situ growth characteristics and behaviour of spoilage organisms associated with anaerobically stored cooked meat products. J Appl Microbiol 98:33-42.

Zwietering MH, de Koos JT, Hasenack BE, de Wit JC, van't Riet K (1991) Modeling of bacterial growth as a function of temperature. Appl Environ Microbiol 57:1094-1101.

All the content of the journal, except where otherwise noted, is licensed under a Creative Commons License CC BY-NC. 